\title{
Influence of 4,4,4-Trifluoro-1-phenyl-1,3-butanedione on Selectivity of All-Solid-State Lithium Ion Electrode Prepared by Using 6,6-Dibenzyl-1,4,8-11-tetraoxacyclotetradecane as Ionophore and Its Application in Human Serum Analysis
}

\author{
Ridvan Yildirim $^{1, *}$, Ismail Agir $^{2}$, Mustafa Nigde $^{1}$, Ibrahim Isildak $^{1}$ \\ ${ }^{1}$ Faculty of Chemical and Metallurgical Engineering, Department of Bioengineering, Yildiz Technical \\ University, 34220, Istanbul, Turkey \\ ${ }^{2}$ Faculty of Engineering and Natural Sciences, Department of Bioengineering, Istanbul Medeniyet \\ University, 34720, Istanbul, Turkey \\ *E-mail: ridvany@yildiz.edu.tr
}

doi: $10.20964 / 2020.11 .30$

Received: 28 July 2020 / Accepted: 1 September 2020 / Published: 30 September 2020

In this work, we aimed to increase the selectivity of lithium selective electrodes containing lithium ionophore VI in the membrane matrix by using 4,4,4-Trifluoro-1-phenyl-1,3-butanedione (HBTA). Potentiometric response characteristics of the prepared lithium selective electrodes were investigated. Increasing the ratio of HBTA molecule in the membrane cocktail from $0.5 \%$ to $1.5 \%$ provided a better response with respect to the lower detection limit (LDL), linear range, and selectivity. The LDL and linear range of the electrode with $1.5 \%$ HBTA were $7.6 \times 10^{-6} \mathrm{~mol} \mathrm{~L}^{-1}$ and $1.0 \times 10^{-1}-3.4 \times 10^{-5} \mathrm{~mol} \mathrm{~L}^{-1}$ respectively, with a slope $54.3 \mathrm{mV} /$ decade $\left(\mathrm{R}^{2}=0.9998\right)$. The potentiometric responses of all electrodes were $\mathrm{pH}$-independent in the range of $\mathrm{pH} \mathrm{3-12.} \mathrm{The} \mathrm{response} \mathrm{time} \mathrm{of} \mathrm{the} \mathrm{electrodes} \mathrm{was} \mathrm{less} \mathrm{than} 10 \mathrm{~s}$ and the lifetime was more than eight weeks. The electrode with $1.5 \%$ HBTA showed a better selectivity against sodium (1:575) and potassium (1:270) and was successfully applied for the determination of lithium levels in diluted human serum samples. The obtained potentiometric data were compared with the ICP-MS results at $98 \%$ confidence level.

Keywords: PVC membrane, all-solid-state contact electrode, bipolar disorder, lithium, potentiometry

\section{$\underline{\text { FULL TEXT }}$}

(C) 2020 The Authors. Published by ESG (www.electrochemsci.org). This article is an open access article distributed under the terms and conditions of the Creative Commons Attribution license (http://creativecommons.org/licenses/by/4.0/). 